\title{
Review of the Clinicopathological Features and Prognosis of the Rare Histological Types of Gastric Cancer
}

\section{Mide Kanserinin Nadir Görülen Histolojik Tiplerinin Klinikopatolojik Özelliklerinin ve Prognozlarının Gözden Geçirilmesi}

\author{
Tutkun Talih $^{1 \oplus}$, Ugur Topal ${ }^{3 \oplus}$, Erdogan Mutevelli Sozuer ${ }^{3 \oplus}$, Fatih Dal ${ }^{1 \oplus}$, Muhammet Akyuz ${ }^{1 \oplus}$ \\ Sadi Yenel Isaogulları ${ }^{1} \oplus$, Kemal Deniz ${ }^{2} \oplus$, Hızır Yakup Akyıldız ${ }^{3} \oplus$ \\ ${ }^{1}$ Department of General Surgery, Erciyes University Medical Faculty, Kayseri, Turkey \\ ${ }^{2}$ Department of Pathology, Erciyes University Medical Faculty, Kayseri, Turkey \\ ${ }^{3}$ Department of Surgical Oncology, Erciyes University Medical Faculty, Kayseri, Turkey
}

Received: 20.07.2020 / Accepted: 17.08.2020 / Published Online: 30.09.2020

Cite as: Talih T, Topal U, Sozuer EM, Dal F, Akyuz M, Isaogullari SY, Deniz K, et al. Review of the clinicopathological features and prognosis of the rare histological types of gastric cancer. Med J Bakirkoy 2020;16(3):301-8.

\begin{abstract}
Objective: Gastric cancer consists of many histological subtypes. Prognostic value of histological types in gastric cancer has not been very well defined. In this study, we aimed to investigate the relationship between different histological types and clinicopathologic features and prognosis in gastric cancer. Method: Patients whose pathological diagnosis was adenosquamous carcinoma, hepatoid adenocarcinoma, lymphoepithelioma-like carcinoma, and papillary adenocarcinoma, among the 1060 patients who underwent gastrectomy for gastric cancer between 2010-2019, were included in the study. Demographic features, clinicopathological features, oncological follow-up results and survival of the patients were analyzed.

Results: Group 1 (adenosquamous carcinoma) consisted of 3, Group 2 (hepatoid adenocarcinoma) of 3, Group 3 (lymphoepithelioma-like carcinoma) of 3, and Group 4 (papillary adenocarcinoma) consisted of 4 patients. The mean age of the patients included in the study was 63.3+11.76 (41-81) years. Tumors were more commonly located in the corpus in hepatoid adenocarcinoma and lymphoma-like carcinoma (67\%) and in the antrum (75\%) in papillary adenocarcinoma. Eight patients underwent total gastrectomy, four patients subtotal gastrectomy, and a patient with a tumor located at the gastroesophageal junction underwent proximal gastrectomy. Average tumor size $(\mathrm{cm})$ was $5.11+2.23(1.2-8) \mathrm{cm}$. Local recurrence occurred in two patients with adenosquamous carcinoma, two with hepatoid adenocarcinoma, and one with papillary adenocarcinoma. Two patients with adenosquamous carcinoma developed systemic metastasis (lung, liver), two patients with hepatoid adenocarcinoma developed peritoneal carcinomatosis, and a patient with papillary adenocarcinoma developed surrenal metastasis. Average survival was the shortest in hepatoid adenocarcinoma (17.50 months), and the longest in papillary adenocarcinoma (63 months). There was no statistical difference in survival between the groups (p: 0.445$)$. Conclusion: Rare histological types of the stomach differed in terms of their locations and prognoses. Among the rare histological types, hepatoid
\end{abstract} adenocarcinoma exhibited the most aggressive biological behavior, while patients with papillary adenocarcinoma had longer survival times.

Keywords: gastric cancer, rare histological type, curative resection, prognosis

Öz

Amaç: Mide kanseri birçok histolojik alt tipten oluşur. Mide kanserinde histolojik tiplerin prognostik değeri iyi tanımlanmamıştır. Bu çalışmada mide kanserinde farklı histolojik tiplerin klinikopatolojik özellikler ve prognoz ile ilişkisini araştırmayı amaçladık.

Yöntem: 2010-2019 yıllları arasında mide kanseri nedeniyle gastrektomi yapılan 1060 hasta arasından patolojik tanısı adenoskuamöz karsinom, hepatoid adenokarsinom, lenfoepitelyoma like karsinom ve papiller adenokarsinom olan hastalar dahil edildi. Hastaların demografik özellikleri, klinikopatolojik özellikleri, onkolojik takip sonuçları ve sağkalımları analiz edildi.

Bulgular: Grup 1 (adenoskuamöz karsinom) 3, Grup 2 (hepatoid adenokarsinom) 3, Grup 3 (lenfoepitelyoma like karsinom) 3 ve Grup 4 (papiller ade-

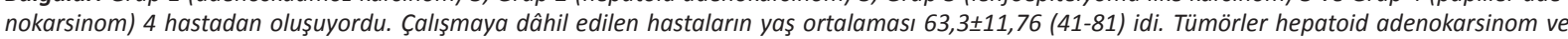
lenfoma like karsinomda korpusta (\%67), papiller adenokarsinom da antrumda (\%75) daha sık saptandı. Sekiz hastaya total gastrektomi dört hastaya subtotal gastrektomi, gastroözofageal-EJ bileşkede yerleşmiş olan tümöre de proksimal gastrektomi uygulandı. Ortalama tümör boyutu (cm) 5,11×2,23 (1,2-8). Adenoskuamöz karsinomlu iki, hepatoid adenokarsinomlu iki ve papiller adenokarsinomlu bir hastada lokal nüks gelişti. Adenoskuamöz karsinomlu iki hastatada sistemik metastaz (akciğer, karaciğer), hepatoid adenokarsinomlu iki hastada peritoneal karsinomatozis ve papiller adenokarsinom tanılı bir hastada da sürrenal metastaz gelişti. Ortalama sağ kalım hepatoid adenokarsinomada en kısa (17,50 ay) iken papiller adenokarsinomada en uzundu. (63 ay). Gruplar arasında sağ kalım açısından istastiksel farklılık yoktu (p: 0,454).

Sonuç: Midenin nadir görülen histolojik tipleri yerleşim yerleri ve prognozları açısından farklılık gösteriyordu. Nadir histolojik tipler arasından hepatoid adenokarsinom en agresif biyolojik davranış sergilerken papiller adenokarsinom diğer histolojik tiplere gore daha uzun sağ kalım sergilemişti.

Anahtar kelimeler: mide kanseri, nadir histolojik tip, küratif rezeksiyon, prognoz

Corresponding Author:

sutopal2005@hotmail.com
T. Talih 0000-0003-3999-6733

U. Topal 0000-0003-1305-2056

E. M. Sozuer 0000-0002-3332-2570

F. Dal 0000-0003-2523-1369
M. Akyuz 0000-0002-2002-8698

S. Y. Isaogulları 0000-0003-3767-7317

K. Deniz 0000-0001-7749-2152

H. Y. Akyıldız 0000-0001-5356-4887

(C) Telif hakkı Sağlık Bilimleri Üniversitesi Bakırköy Dr. Sadi Konuk Eğitim ve Araştırma Hastanesi'ne aittir. Logos Tıp Yayıncılık tarafindan yayınlanmaktadır. Bu dergide yayınlanan bütün makaleler Creative Commons Attf-GayriTicari 4.0 Uluslararası Lisansı ile lisanslanmıştır.

(c) Copyright Health Sciences University Bakırköy Sadi Konuk Training and Research Hospital. This journal published by Logos Medical Publishing.

Licenced by Creative Commons Attribution-NonCommercial 4.0 International (CC BY) 


\section{INTRODUCTION}

Gastric cancer is the fifth most common cancer in the world and is the third most common cause of cancer-related deaths after lung and colorectal cancer ${ }^{(1)}$. Gastric cancer is considered a heterogeneous disease. Each histological subtype of stomach cancer has different characteristics as biological behavior, therefore histological type is an important place in the individual evaluation of stomach cancer patients $(2,3)$.

There are various histopathological classification systems for the diagnosis of gastric cancer. The most detailed classification system is the histopathological classification system made by the World Health Organization (WHO) in 2010 and updated in 2019. Unlike other systems, the WHO classification includes all other types of rarely seen gastric tumors other than gastric adenocarcinoma ${ }^{(4,5)}$.

In all types of gastric cancer, the most common type of pathology is adenocarcinoma (AC) ${ }^{(4,6)}$. Primary gastric adenosquamous carcinoma (ASC) is characterized by the presence of adenocarcinoma and squamous cell carcinoma (SCC) components within the same tumor. This extremely rare histological type accounts for less than $1 \%$ of gastric carcinomas and exhibits aggressive behavior $(7,8)$.

Hepatoid adenocarcinoma (HAC) is a rare tumor with extrahepatic origin, characterized by the imitation of the morphological phenotype of hepatocellular carcinoma (HCC). Hepatoid adenocarcinoma not only shares the morphological features of HCC, but its alpha-fetoprotein (AFP) production and immunohistochemical properties resembles HCC ${ }^{(9,10)}$. While hepatoid adenocarcinoma is seen in many organs such as the lung, pancreas, ovary, uterus and gall bladder, the most frequently affected organ is the stomach. It accounts for only 0.38 to $1.00 \%$ of all gastric cancers (GC) ${ }^{(9,11)}$. HAC is an aggressive tumor with a poor prognosis that tends to metastasize to the liver and lung at an early stage ${ }^{(12)}$.

Papillary adenocarcinoma of the stomach is defined as a well-differentiated exophytic gastric carcinoma with elongated finger-like processes lined by cylindrical or cuboidal cells supported by fibromuscular connective tissue cores ${ }^{(6)}$. Papillary adenocarcinomas of the stomach make up only $6-11 \%$ of all gastric carcinoma cases. Papillary adenocarcinoma type of the stomach shows increased lymphovascular invasion, liver metastasis and poor survival compared to other adenocarcinoma subtypes ${ }^{(13,14)}$.

Lymphoepithelioma-like gastric carcinoma (LELGC) is a rare gastric cancer subtype characterized by lymphocytic infiltration of the tumor stroma. This histological type, which accounts for $1.4 \%$ of all gastric carcinomas, may be associated with Epstein- Barr virus (EBV) infection or microsatellite instability (MSI). The prognosis of LELGC is better than other types of gastric carcinoma ${ }^{(15,16)}$.

In this study, we aimed to discuss the surgical results and prognoses of the rarer histologic types of gastric carcinoma, which are adenosquamous carcinoma, hepatoid adenocarcinoma, papillary adenocarcinoma, and lymphoepithelioma-like carcinoma, within a 10 -year period in our clinic, in the light of the literature.

\section{MATERIALS and METHODS}

After the approval of the Ethics Committee of Erciyes University Faculty of Medicine dated 10.06.2020 and numbered 2020/270, 13 patients who had the pathological diagnosis of adenosquamous carcinoma, hepatoid adenocarcinoma, papillary adenocarcinoma and lymphoepithelioma-like carcinoma, out of the 1060 patients who underwent curative surgery in our clinic between 2010-2019, were included in the study. Mixed tumors accompanied by this histological type, other histological subtypes, and patients undergoing palliative surgery were excluded from the study.

Patient files, electronic records, pathology reports, surgery reports, anesthesia follow-up forms, and nurse observation forms were examined, and a common database was created prospectively. Patients were analyzed retrospectively using this database. The population registration system was used for survival analysis.

Demographic and clinical features, tumor marker levels, tumor localizations, surgical procedure, total number of lymph nodes dissected, number of metastatic lymph nodes, tumor size, local recurrence and systemic 


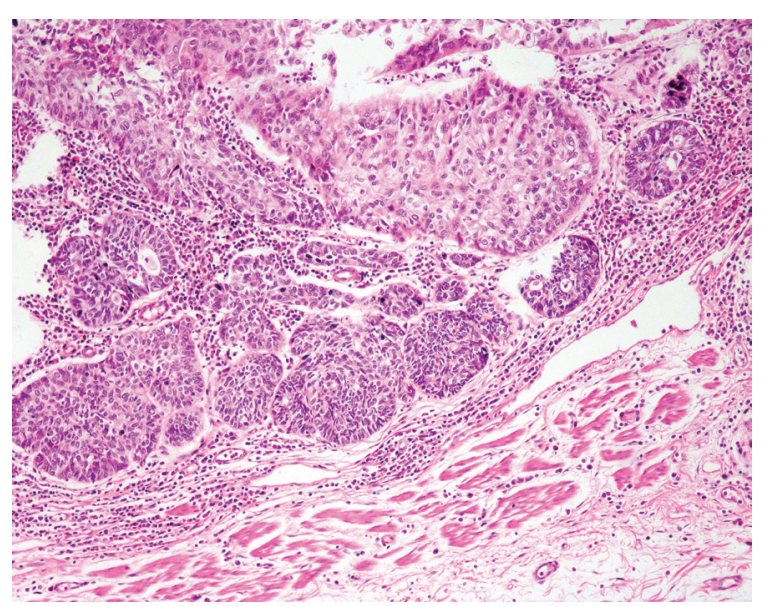

Figure 1. Adenosquamous carcinoma.

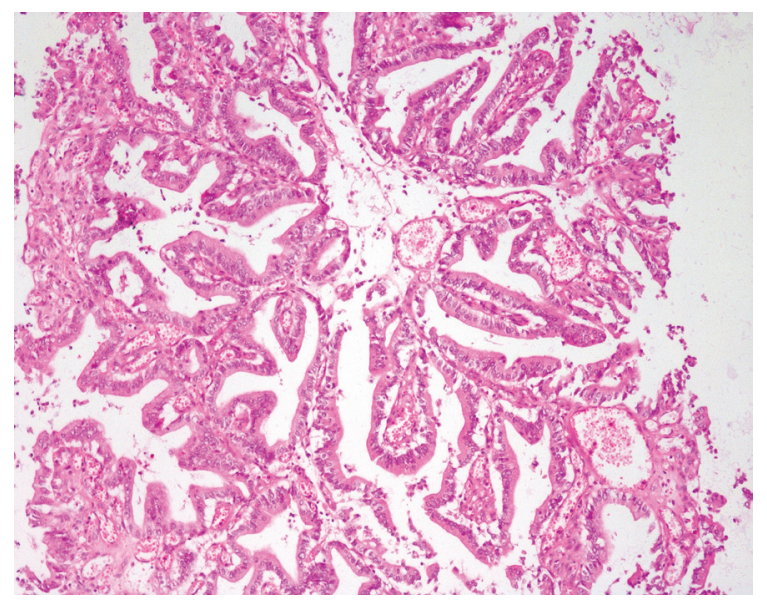

Figure 3. Papillary adenocarcinoma.

metastasis, and mean survival times were analyzed.

Chest radiography, abdominal sonography or abdominal computed tomography scans were performed to all patients prior to the operation for tumor staging. Histological subtypes were classified using the World Health Organization (WHO) classification ${ }^{(4,5)}$. All surgical samples were reviewed by a senior pathologist from our institution (Figure 1, 2, 3, 4).

The patients were operated with conventional techniques. Total gastrectomy and subtotal gastrectomy were performed using the previously recognized and accepted Japanese Gastric Cancer Association criteria ${ }^{(17,18)}$. The location and size of the tumor were effective in choosing the type of resection.

Tumor recurrence at the hepatoduodenal ligament,

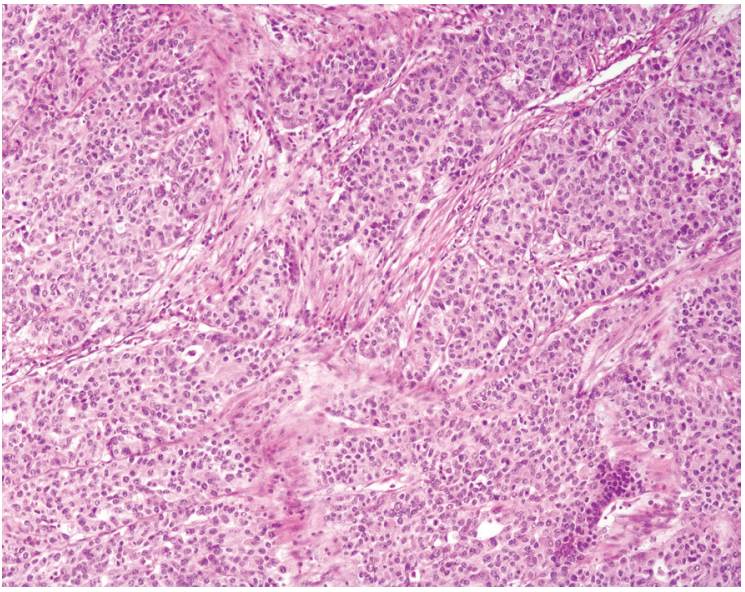

Figure 2. Hepatoid adenocarcinoma.

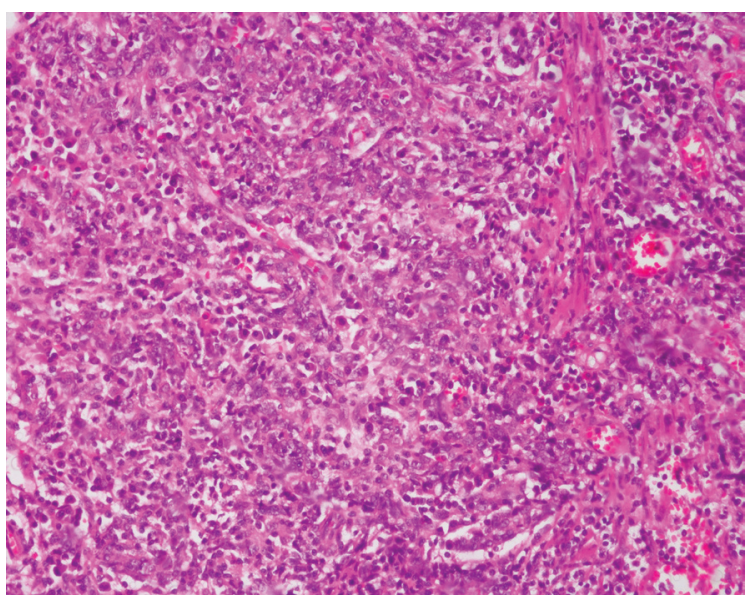

Figure 4. Lymphoepithelioma-like carcinoma.

celiac axis, peripancreatic region and operation site was considered as local recurrence. Peritoneal relapses and other organ metastases were considered as systemic metastases.

Overall survival time was calculated as the time from surgery to death or last follow-up. In the follow-up of the patients, evaluations were made every 3 months for the first 2 years after the operation and every 6 months afterwards.

SPSS (Statistical Package for the Social Sciences) 23.0 package program was used for statistical analysis of the data. Continuous measurements were summarized as mean and standard deviation (minimummaximum). Kaplan-Meier analysis and Log Rank tests were used in survival analyses. Statistical significance level was taken as 0.05 in all tests. 


\section{RESULTS}

Thirteen patients were included in our study. The $M / F$ ratio of the patients was $7 / 6$. The average age of the patients participating in the study was $63.3 \pm 11.76$ (41-81) years. Tumors were most commonly located in the corpus and antrum. Eight patients underwent total gastrectomy, four patients subtotal gastrectomy, and a patient with a tumor located at the gastroesophageal junction underwent proximal gastrectomy. Average tumor size was $5.11 \pm 2.23(1.2-8) \mathrm{cm}$. Local recurrence occurred in two patients with adenosquamous carcinoma, two with hepatoid adenocarcinoma, and one with papillary adenocarcinoma.
Two patients with adenosquamous carcinoma developed systemic metastasis (lung, liver), two patients with hepatoid adenocarcinoma peritoneal carcinomatosis, and a patient with papillary adenocarcinoma surrenal metastasis. The clinical characteristics and follow-up results of the patients are shown in Table 1.

When we look at the mean survival times, hepatoid adenocarcinoma showed the worst survival with 17.50 months and papillary adenocarcinoma had the best survival with 63 months ( $p: 0.445$ ). Survival analysis and curves are given in Table 2 and Graphic 1.

Table 1. Patients characteristics.

\begin{tabular}{|c|c|c|c|c|c|c|c|c|c|}
\hline Tumor Type & Age/sex & Location & $\begin{array}{l}\text { CEA/Ca19.9 } \\
\text { (ng/ml-U/ml) }\end{array}$ & $\begin{array}{l}\text { Surgical } \\
\text { Procedure }\end{array}$ & $\begin{array}{l}\text { Tumor } \\
\text { size }\end{array}$ & $\begin{array}{l}\text { Total/Metastatic } \\
\text { lymph node }\end{array}$ & $\begin{array}{l}\text { Local } \\
\text { recurrence }\end{array}$ & $\begin{array}{l}\text { Systemic } \\
\text { metastasis }\end{array}$ & $\begin{array}{l}\text { Current } \\
\text { status }\end{array}$ \\
\hline Adeno-squamous carcinoma & $81 / \mathrm{M}$ & $\begin{array}{c}\text { Small } \\
\text { curvature }\end{array}$ & $0.11 / 75.72$ & $\begin{array}{c}\text { Total } \\
\text { Gastrectomy }\end{array}$ & 8 & $10 / 4$ & Yes & Lung & $\begin{array}{c}\text { Died } \\
3 \text { months }\end{array}$ \\
\hline Adeno-squamous carcinoma & $41 / F$ & Corpus & $2 / 50$ & $\begin{array}{c}\text { Subtotal } \\
\text { Gastrectomy }\end{array}$ & 6 & $12 / 0$ & Yes & Liver & $\begin{array}{c}\text { Died } \\
12 \text { months }\end{array}$ \\
\hline Adeno-squamous carcinoma & $67 / F$ & G-EJ & $2.31 / 30.4$ & $\begin{array}{c}\text { Proksimal } \\
\text { Gastrectomy }\end{array}$ & 1.2 & $23 / 0$ & No & No & $\begin{array}{l}\text { Alive } 40 \\
\text { months }\end{array}$ \\
\hline Hepatoid adenocarcinoma & $76 / F$ & Corpus & $42.16 / 8.47$ & $\begin{array}{c}\text { Total } \\
\text { Gastrectomy }\end{array}$ & 8 & $23 / 8$ & Yes & $\begin{array}{c}\text { Peritoneal } \\
\text { Carcinomatosis }\end{array}$ & $\begin{array}{c}\text { Died } \\
7 \text { months }\end{array}$ \\
\hline Hepatoid adenocarcinoma & $71 / \mathrm{M}$ & Corpus & $314.58 / 19.9$ & $\begin{array}{c}\text { Total } \\
\text { Gastrectomy }\end{array}$ & 2.5 & $25 / 0$ & Yes & $\begin{array}{c}\text { Peritoneal } \\
\text { Carcinomatosis }\end{array}$ & $\begin{array}{c}\text { Died } \\
3 \text { months }\end{array}$ \\
\hline Hepatoid adenocarcinoma & $57 / \mathrm{M}$ & $\begin{array}{c}\text { Small } \\
\text { curvature }\end{array}$ & $18.27 / 232$ & $\begin{array}{c}\text { Total } \\
\text { Gastrectomy }\end{array}$ & 5 & $22 / 4$ & No & No & $\begin{array}{c}\text { Alive } \\
37 \text { months }\end{array}$ \\
\hline Lymphoepithelioma-like carcinoma & $72 / \mathrm{M}$ & Corpus & $3.74 / 19.54$ & $\begin{array}{c}\text { Total } \\
\text { Gastrectomy }\end{array}$ & 5 & $22 / 8$ & No & No & $\begin{array}{c}\text { Died } \\
23 \text { months }\end{array}$ \\
\hline Lymphoepithelioma-like carcinoma & $54 / \mathrm{M}$ & Corpus & $2 / 11$ & $\begin{array}{c}\text { Total } \\
\text { Gastrectomy }\end{array}$ & 5 & $33 / 0$ & No & No & $\begin{array}{c}\text { Died } \\
4 \text { months }\end{array}$ \\
\hline Lymphoepithelioma-like carcinoma & $54 / F$ & Antrum & $1.24 / 2.64$ & $\begin{array}{c}\text { Subtotal } \\
\text { Gastrectomy }\end{array}$ & 4.5 & $28 / 1$ & No & No & $\begin{array}{c}\text { Alive } \\
58 \text { months }\end{array}$ \\
\hline Papillary & $69 / F$ & Corpus & $3.95 / 20.83$ & $\begin{array}{c}\text { Total } \\
\text { Gastrectomy }\end{array}$ & 2 & $8 / 0$ & No & Surrenal & $\begin{array}{c}\text { Died } \\
57 \text { months }\end{array}$ \\
\hline Adenocarcinoma & $47 / \mathrm{M}$ & Antrum & $23.02 / 562.38$ & $\begin{array}{c}\text { Subtotal } \\
\text { Gastrectomy }\end{array}$ & 6.5 & $15 / 3$ & Yes & No & $\begin{array}{c}\text { Died } \\
53 \text { months }\end{array}$ \\
\hline Papillary & $66 / F$ & Antrum & $3.07 / 32.23$ & $\begin{array}{c}\text { Subtotal } \\
\text { Gastrectomy }\end{array}$ & 4.75 & $18 / 0$ & No & No & $\begin{array}{c}\text { Alive } \\
76 \text { months }\end{array}$ \\
\hline Adenocarcinoma & $68 / \mathrm{M}$ & Antrum & $7 / 100$ & $\begin{array}{c}\text { Total } \\
\text { Gastrectomy }\end{array}$ & 8 & $33 / 0$ & No & No & $\begin{array}{c}\text { Alive } \\
50 \text { months }\end{array}$ \\
\hline
\end{tabular}

Table 2. Mean survival in the groups.

\begin{tabular}{lcc}
\hline Groups & Mean (Mean + sd (Min Max)) & Median (Mean + sd (Min Max)) \\
Adeno-squamous carcinoma & $20.10 \pm 10.33(3-40.36)$ & $12.50 \pm 7.76(0-27.72)$ \\
Hepatoid adenocarcinoma & $17.50 \pm 10.40(3-37.90)$ & $6.59 \pm 2.93(0.83-12.35)$ \\
Lymphoepithelioma-like carcinoma & $31.58 \pm 13.87(4.39-58.77)$ & $25.34 \pm 15.97(0-56.66)$ \\
Papillary adenocarcinoma & $63.32 \pm 6.77(50.04-76.59)$ & $57.32 \pm 3.59(50.28-64.36)$
\end{tabular}




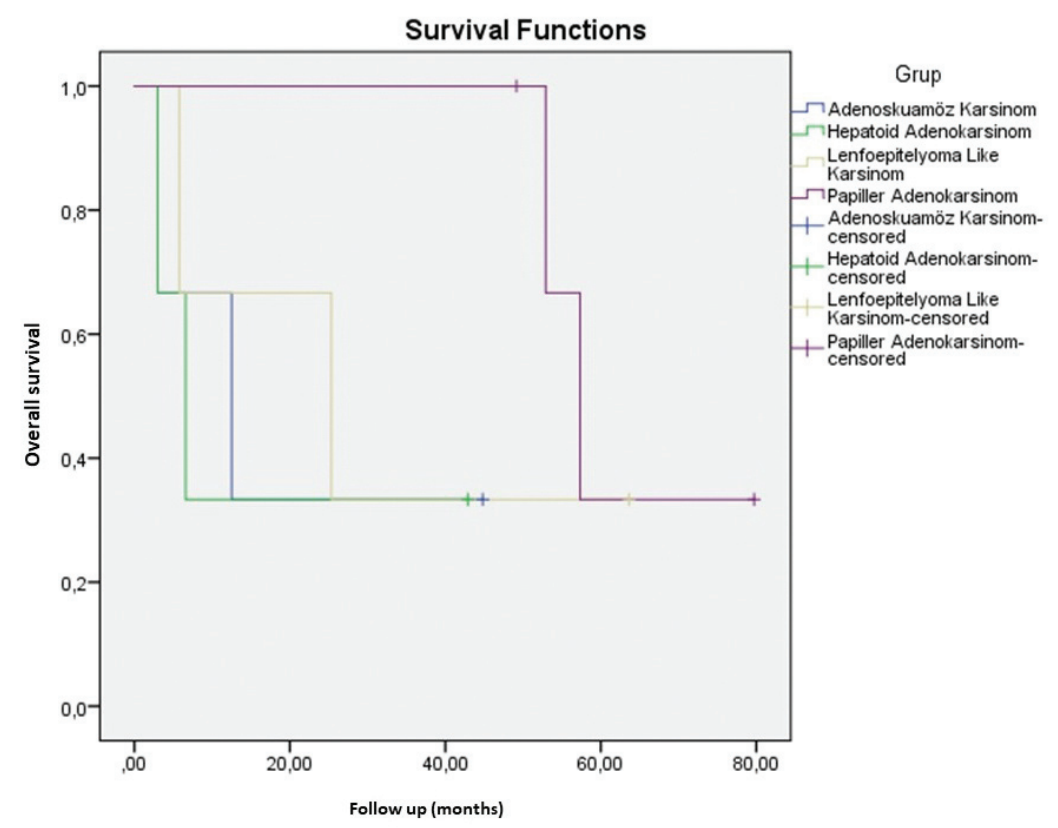

Figur 5. Overall survival in terms of the histological type.

\section{DISCUSSION}

There are many histological type classifications for gastric cancer such as Lauren classification, Ming classification and WHO classification ${ }^{(4,6,8,19)}$. Today, WHO classification is widely used worldwide.

Although the prognosis of resectable gastric cancer clearly depends on the pathological stage of the disease, controversy continues about the prognostic value of the histological type. The histological type appears to be an important clinical parameter of a tumor and is suggested as an important factor in evaluating the patient's prognosis ${ }^{(20)}$. However, controversy continues on clinicopathological features and prognostic factors.

Gastric adenosquamous carcinoma is a rare histological type of gastric cancer. Often, venous and lymphatic invasion are found in patients presenting at an advanced stage. The biological behavior of adenosquamous carcinoma has been reported to be more aggressive than adenocarcinoma. Biological behavior in gastric adenosquamous carcinoma is usually determined by its adenocarcinoma component. Hematogenous and hepatic metastases are more common in tumors which predominantly have adenocarcinoma components ${ }^{(21)}$.
Because of its rarity, no standard treatment for primary gastric ASC has been established. Surgical resection remains the most commonly used treatment method. However, due to the fact that it is diagnosed at an advanced stage, surgical treatment has been shown to be applied in approximately $54 \%$ $-74 \%$ of large series in the literature ${ }^{(7,21)}$. Akce et al. published a rate of $71 \%$ lymph node positivity for ASC in their study using National Cancer Database which included data of 327 patients ${ }^{(7)}$. Feng et al. found the median overall survival time to be 17 months, with 1-, 3-, and 5-year overall survival rates being $58.1 \%, 32.4 \%$ and $26.4 \%$, respectively, in their study of 109 patients (21 patients from their center + 88 patients from Medline search who met inclusion criteria) with adenosquamous carcinoma undergoing RO resection ${ }^{(8)}$. Tumor location was effective in our selection of treatment in adenosquamous tumor in our series. Lymph node involvement was detected in $33 \%$ of our patients. Compared to the literature, our lymph node involvement rate was lower. The course of these tumors was highly aggressive, and recurrent and systemic metastasis developed in 2 patients. The survival rate was 20 months on average.

Pathological diagnosis in HAC is made based on morphological features, regardless of serum AFP levels or immunohistochemical AFP staining. The primary 
HAC lesion contains tubular as well as hepatoid components ${ }^{(12)}$. The scientific literature on this topic mostly includes single case reports and some small single institution patient series ${ }^{(12,22)}$.

In the 328 patients series (34 patients from their center +294 patients from Medline search) performed by Zeng et al., HAC was most commonly located in the antrum (45.6\%) followed by corpus (31.3\%). Distant metastasis was present at the time of diagnosis in $36.9 \%$ of the patients. Lymph node metastasis occurred in $78.4 \%$. of the patients. The median tumor diameter was $5.5 \mathrm{~cm}{ }^{(23)}$. Adachi et al. found a 5 -year survival rate of $22 \%$ in all patients and a median survival time of 14 months, in their Japanese literature series involving 270 cases ${ }^{(24)}$. When they examined patients undergoing curative gastrectomy, they found a 5 -year survival rate of $42 \%$ and a median survival time of 29 months. Survival time was affected by serum AFP level, tumor size, lymphovascular involvement, lymph node, and liver metastasis. In their series, this poor prognosis was mostly due to peritoneal spread and early recurrence in the liver ${ }^{(24)}$.

Unlike the literature, HACs were located in the corpus and small curvature in our series. There was no HAC with antrum localization in our series. All patients underwent total gastrectomy. Average tumor diameter was $5 \mathrm{~cm}$ in our series similar to that reported in the literature reported two of our patients had lymphatic involvement. These tumors exhibited aggressive behavior and caused peritoneal carcinomatosis. Patients who developed peritoneal carcinomatosis, died early.

Lymphoepithelioma like carcinoma is defined as tumors that show histological similarity with nasopharyngeal carcinoma. The LELGC of the stomach was first described by Watanabe et al. ${ }^{(25)}$ as a gastric carcinoma accompanied by a lymphoid stroma. Lymphoid stroma contains CD8- or CD4-positive T lymphocytes and CD68-positive macrophages. EBV infection is only observed in a very limited number of these infiltrating lymphocytes ${ }^{(26)}$.

In the series of Tak, DH., 77\% of the patients had tumors at corpus localization corpus localization (27). Gastric LELGC is generally known to have a better prognosis than conventional gastric carcinomas. In a study comparing a LELGC series with 46 patients with adisease non-lymphoepithelioma-like carcinoma (NLELC) series with 42236, patients Park et al. found the lymphatic invasion rate to be lower (17\% vs $36 \% \mathrm{p}: 0.008)$. The frequency of lymph node involvement in LELGC was $28.3 \%$ in their series. The 5 -year survival rate of patients with LELGC was $97.7 \%$ and $89.4 \%$ in the NLELC group (p:0.127) in this study, age, tumor location, depth of invasion, lymph node metastasis and venous invasion were found as prognostic indicators ${ }^{(28)}$. In their study, Tak et al. reported that postoperative recurrence or metastasis tends to occur less frequently in patients with LELGC than in patients with poorly differentiated gastric carcinoma ${ }^{(27)}$. In our series, LELGC tumors were most frequently seen in the corpus, similar to the literature. Lymph node involvement was present in two patients and the rate of involvement was higher than in the literature. Similar to the literature, there was no local recurrence or systemic metastasis in these patients. Survival rates were shorter with an average of 31 months compared to the literature.

There are several studies in the literature reporting that patients with papillary adenocarcinoma have a worse prognosis than those with other differentiated types ${ }^{(13)}$. The reliability of endoscopic submucosal dissection (ESD) has been controversial in patients with papillary adenocarcinoma because of higher rates of lymph node and liver metastasis, and a low 5 -year survival rate when compared to those with non-papillary adenocarcinoma. Studies have been conducted on ESD safety in papillary carcinoma (29-30). Lee et al., in their series involving early gastric cancers-papillary (EGC-P) patients, found the most common tumor localization to be the lower third of the stomach (76.8\%) and the mean tumor diameter as $3 \mathrm{~cm}$ in the same study ${ }^{(29)}$. Yasuda et al., in their 632 disease series comparing patients with papillary adenocarcinoma (PGC) to non-papillary gastric carcinomas (NGC), found the 5 -year survival rate to be significantly lower in PGC patients compared to NGC patients (63\% vs. $76 \%)^{(14)}$. In patients with papillary adenocarcinoma in our series, the tumor was most frequently located in the antrum, similar to the literature. Unlike the literature, average tumor diameter in our series was $5 \mathrm{~cm}$, and unlike the literature, liver metastasis did not develop. Survival 
rates were found to be 63 months. Only one patient had lymph node metastasis and we thought that survival was related to the tumor stage.

The most important limitation of our study was the limited number of patients, but considering the low incidence of these tumors, it was acceptable. However, we believe that the present study will contribute to the literature when we consider the limited number of studies in the literature on the combination and comparison of the results of these rare histological types.

\section{CONCLUSION}

The histological types of gastric cancer differed in terms of their location and prognosis. Among the rare histological types, hepatoid adenocarcinoma showed the most aggressive biological behavior, while, as expected, patients with papillary adenocarcinoma had a longer survival times than those with other histological types.

Ethics Committee Approval: It has been approved by the Erciyes University Clinical Research Ethics Committee (2020/270).

Conflict of Interest: There is no conflict of interest.

Funding: There are no financial supports.

Informed Consent: Because the study was retrospective, patient consent could not be obtained.

\section{REFERENCES}

1. Bray F, Ferlay J, Soerjomataram I, Siegel RL, Torre LA, Jemal A. Global cancer statistics 2018: GLOBOCAN estimates of incidence and mortality worldwide for 36 cancers in 185 countries. CA Cancer J Clin. 2018;68(6):394-424.

https://doi.org/10.3322/caac.21492

2. Chu YX, Gong HY, Hu QY, Song QB. Adenosquamous carcinoma may have an inferior prognosis to signet ring cell carcinoma in patients with stages I and II gastric cancer. World J Gastrointest Oncol. 2020;12(1):10112.

https://doi.org/10.4251/wjgo.v12.i1.101

3. Sert OZ, Gulmez S, Uzun O, Bozkur H, Gunes $\mathrm{OH}$. Gastric mixed adeno-neuroendocrine carcinoma with a large cell neuroendocrine component A case reports. Ann Ital Chir. 2019;8. PMID: 31790369.

4. Bosman FT, Carneiro F, Hruban RH, Theise ND, eds. WHO classification of tumours of the digestive system vol. 3. 4th ed. Lyon: International Agency for Research on Cancer; 2010.

5. Nagtegaal ID, Odze RD, Klimstra D, Paradis V, Rugge M,
Schirmacher P, et al. The 2019 WHO classification of tumours of the digestive system. Histopathology. 2020;76(2):182-8. https://doi.org/10.1111/his.13975

6. Lauwers GY, Carneiro F, Graham DY, Curado CM. Tumours of the stomach. In: Bosman FT, Carneiro F, Hruban RH Theise ND, editors. WHO Classification of Tumours of the Digestive System. 4 th. Lyon: IARC; 2010. p. 48-58.

7. Akce $M$, Jiang $R$, Alese $O B$, Shaib $W L, W u ~ C$, Behera $M$, et al. Gastric squamous cell carcinoma and gastric adenosquamous carcinoma, clinical features and outcomes of rare clinical entities: A National Cancer Database (NCDB) analysis. J Gastrointest Oncol. 2019;10(1):85-94. https://doi.org/10.21037/jgo.2018.10.06

8. Feng $F$, Zheng G, Qi J, Xu G, Wang F, Wang $Q$, et al. Clinicopathological features and prognosis of gastric adenosquamous carcinoma. Sci Rep. 2017;7(1):4597. https://doi.org/10.1038/s41598-017-04563-2

9. Chen E-B, Wei Y-C, Liu H-N, Tang C, Liu M-L, Peng K, et al. Hepatoid adenocarcinoma of stomach: Emphasis on the clinical relationship with alpha-fetoprotein-positive gastric cancer. Biomed Res Int. 2019;2019: 6710428. https://doi.org/10.1155/2019/6710428

10. Wang Y, Sun L, Li Z, Gao J, Ge S, Zhang C, et al. Hepatoid adenocarcinoma of the stomach: a unique subgroup with distinct clinicopathological and molecular features Gastric Cancer. 2019;22(6):1183-92. https://doi.org/10.1007/s10120-019-00965-5

11. Søreide JA, Greve OJ, Gudlaugsson E, Størset S. Hepatoid adenocarcinoma of the stomach - Proper identification and treatment remain a challenge. Scand J Gastroenterol. 2016;51(6):646-53. https://doi.org/10.3109/00365521.2015.1124286

12. Søreide JA. Therapeutic approaches to gastric hepatoid adenocarcinoma: Current perspectives. Ther Clin Risk Manag. 2019;15:1469-77 https://doi.org/10.2147/TCRM.S204303

13. Yu H, Fang C, Chen L, Shi J, Fan X, Zou X, et al. Worse prognosis in papillary, compared to tubular, early gastric carcinoma. J Cancer. 2017;8(1):117-23. https://doi.org/10.7150/jca.17326

14. Yasuda K, Adachi Y, Shiraishi N, Maeo S, Kitano S. Papillary adenocarcinoma of the stomach. Gastric Cancer. 2000;3(1):33-8. https://doi.org/10.1007/PL00011687

15. Chetty R. Gastrointestinal cancers accompanied by a dense lymphoid component: an overview with special reference to gastric and colonic medullary and lymphoepithelioma-like carcinomas. J Clin Pathol. 2012;65(12):1062-5. https://doi.org/10.1136/jclinpath-2012-201067

16. Cao H, Xie J, Qian Y, Wu Y, Tang Z. Lymphoepitheliomalike gastric carcinoma treated with partial gastrectomy: Two case reports. Oncol Lett. 2019;18(1):545-52. https://doi.org/10.3892/ol.2019.10368

17. Association JGC. Japanese gastric cancer treatment guidelines 2014 (ver. 4). Gastric Cancer. 2017;20(1):119. https://doi.org/10.1007/s10120-016-0622-4

18. Sano T, Kodera Y. Japanese classification of gastric carcinoma: 3rd English edition. Gastric Cancer. 2011;14(2):101-12. 
https://doi.org/10.1007/s10120-011-0041-5

19. Lauren P. The two histological main types of gastric carcinoma: diffuse and so-called intestinal-type carcinoma. An attempt at a histo-clinical classification. Acta Pathol Microbiol Scand. 1965;64:31-49.

https://doi.org/10.1111/apm.1965.64.1.31

20. Park JM, Jang YJ, Kim JH, Park SS, Park SH, Kim SJ, et al. Gastric Cancer histology: Clinicopathologic characteristics and prognostic value. J Surg Oncol. 2008;98(7): 520-5. https://doi.org/10.1002/jso.21150

21. Chen YY, Li AFY, Huang KH, Lan YT, Chen MH, Chao Y, et al. Adenosquamous carcinoma of the stomach and review of the literature. Pathol Oncol Res. 2015;21(3):547-51. https://doi.org/10.1007/s12253-014-9890-7

22. Yang J, Wang R, Zhang W, Zhuang W, Wang $M$, Tang C. Clinicopathological and prognostic characteristics of hepatoid adenocarcinoma of the stomach. Gastroenterol Res Pract. 2014;2014. https://doi.org/10.1155/2014/140587

23. Zeng $X Y$, Yin YP, Xiao $H$, Zhang P, He J, Liu WZ, et al. Clinicopathological characteristics and prognosis of hepatoid adenocarcinoma of the stomach: evaluation of a pooled case series. Curr Med Sci. 2018;38(6):105461. https://doi.org/10.1007/s11596-018-1983-1

24. Adachi Y, Tsuchihashi J, Shiraishi N, Yasuda K, Etoh T, Kitano S. AFP-producing gastric carcinoma: multivariate analysis of prognostic factors in 270 patients. Oncology. 2003;65(2):95-101. https://doi.org/10.1159/000072332

25. Watanabe H, Enjoji M, Imai T. Gastric carcinoma with lymphoid stroma. Its morphologic characteristics and prognostic correlations. Cancer. 1976;38:232-43. https://doi.org/10.1002/1097-0142(197607)38:1<232 ::AID-CNCR2820380135>3.0.CO;2-4

26. Fukayama M, Ushiku T. Epstein-Barr virus-associated gastric carcinoma. Pathol Res Pract. 2011;207(9):52937. https://doi.org/10.1016/j.prp.2011.07.004

27. Tak DH, Jeong HY, Seong JK, Moon HS, Kang SH. Comparison of clinical characteristics and prognostic factors between gastric lymphoepithelioma-like carcinoma and gastric adenocarcinoma. Korean J Gastroenterol. 2013;62(5):272-7. https://doi.org/10.4166/kjg.2013.62.5.272

28. Park S, Choi M-G, Kim K-M, Kim HS, Jung S-H, Lee JH, et al. Lymphoepithelioma-like carcinoma: a distinct type of gastric cancer. J Surg Res. 2015;194(2):458-63. https://doi.org/10.1016/j.jss.2014.12.005

29. Lee HJ, Kim GH, Park DY, Kim YK, Jeon HK, Lee BE, et al. Endoscopic submucosal dissection for papillary adenocarcinoma of the stomach: is it really safe? Gastric Cancer. 2017;20(6):978-86. https://doi.org/10.1007/s10120-017-0709-6

30. Park JH, Kim JS, Kang SH, Moon HS, Sung JK, Jeong HY. Efficacy and safety of endoscopic submucosal dissection for papillary adenocarcinoma-type early gastric cancer. Medicine (Baltimore). 2019;98(25):e16134. https://doi.org/10.1097/MD.0000000000016134 